\title{
Instant messaging application for the care of people living with HIV/aids
}

\author{
Aplicativo de mensagens instantâneas no cuidado às pessoas vivendo com HIV/aids \\ Aplicación de mensajes instantáneos en el cuidado a las personas que viven con VIH/sida
}

Ivana Cristina Vieira de Lima' ORCID: 0000-0002-2698-9086

Marli Teresinha Gimeniz Galvão' ORCID:0000-0003-3995-9107

Samyla Citó Pedrosa' ORCID: 0000-0002-3611-7310 Odaleia Oliveira Farias' ORCID: 0000-0002-3700-1192

Camila Aparecida Costa Silva' ORCID: 0000-0002-9066-4112

Gilmara Holanda da Cunha' ORCID: 0000-0002-5425-1599

'Universidade Federal do Ceará. Fortaleza, Ceará, Brazil.

How to cite this article:

Lima ICV, Galvão MTG, Pedrosa SC, Farias OO, Silva CAC, Cunha GH. Instant messaging application for the care of people living with HIV/aids. Rev Bras Enferm. 2019;72(5):1161-6. doi: http://dx.doi.org/10.1590/0034-7167-2017-0698

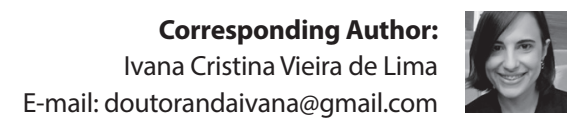

Submission: 10-02-2017

Approval: 04-19-2018

\begin{abstract}
Objective: To assess a specific instant messaging application as a tool of care for people living with HIV/aids, based on analysis of the interactions between nurse and patients. Method: Descriptive, quantitative study with 102 patients from two outpatient infectious disease clinics of Fortaleza, Ceará. During four months, participants received a message every 15 days, totaling eight messages, regarding: adherence to antiretroviral therapy; physical activity; social support; self-esteem; anxiety/depression; eating habits; alcohol and drugs; and sexuality. Results: There were 816 interactions, especially for dialogs about performing physical activity (27.87\%), sharing of signs and symptoms (18.03\%), report of engagement with treatment $(9.84 \%)$ and requests of information on the intake of medicine $(9.84 \%)$. Most participants showed satisfaction with the follow-up, with willingness to continue receiving messages (90.58\%). Conclusion: The use of this application is a viable strategy to improve care for people with HIV by promoting instant communication.

Descriptors: Mensagem de Texto; Telefones Celulares; Comunicação; Cuidados de Enfermagem; HIV.
\end{abstract}

\section{RESUMO}

Objetivo: Avaliar o aplicativo de mensagens instantâneas como ferramenta de cuidado às pessoas vivendo com HIV/aids, a partir da análise das interações entre enfermeiro e pacientes. Método: Estudo descritivo, quantitativo com 102 pacientes de dois ambulatórios de infectologia de Fortaleza, Ceará. Durante quatro meses, os participantes receberam uma mensagem a cada 15 dias, totalizando oito mensagens, sobre: adesão à terapia antirretroviral; atividade física; apoio social; autoestima; ansiedade/depressão; hábitos alimentares; álcool e drogas; e sexualidade. Resultados: Houve 816 interações, com destaque para os diálogos sobre realização de atividade física (27,87\%), compartilhamento de sinais e sintomas $(18,03 \%)$, relato de engajamento com o tratamento $(9,84 \%)$ e requisição de informações sobre tomada de medicamentos $(9,84 \%)$. A maioria dos participantes demonstrou satisfação com o acompanhamento, com desejo de continuar recebendo as mensagens $(90,58 \%)$. Conclusão: $O$ uso desse aplicativo é uma estratégia viável para incrementar o cuidado às pessoas com HIV, por promover comunicação instantânea. Descritores: Mensagem de Texto; Telefones Celulares; Comunicação; Cuidados de Enfermagem; HIV.

\section{RESUMEN}

Objetivo: Evaluar la aplicación de mensajes instantáneos como herramienta de cuidado a las personas que viven con $\mathrm{VIH} /$ sida, a partir del análisis de las interacciones entre enfermero y pacientes. Método: Estudio descriptivo, cuantitativo con 102 pacientes de dos ambulatorios de infectología de Fortaleza (Ceará, Brasil). Durante cuatro meses, los participantes recibieron un mensaje cada 15 días, resultando en ocho mensajes, acerca de: adhesión a la terapia antirretroviral; actividad física; apoyo social; autoestima; ansiedad/depresión; hábitos alimentarios; alcohol y drogas; y sexualidad. Resultados: Se realizaron 816 interacciones, con destaque para los diálogos sobre la realización de actividad física $(27,87 \%)$, compartimiento de señales y síntomas $(18,03 \%)$, relato de compromiso con el tratamiento $(9,84 \%)$ y solicitud de información acerca de la toma de medicamentos $(9,84 \%)$. La mayoría de los participantes demostró satisfacción en cuanto al seguimiento, y manifestó el deseo de seguir recibiendo mensajes $(90,58 \%)$. Conclusión: El uso de esta aplicación es una estrategia viable para incrementar el cuidado a las personas con VIH, por promover la comunicación instantánea.

Descriptores: Mensajes de Texto; Teléfonos Celulares; Comunicación; Cuidados de Enfermería; VIH. 


\section{INTRODUCTION}

Advancements in the treatment of HIV/aids have contributed to the transition from acute to chronic condition disease. Highly active anti-retroviral therapy represented a major achievement against evolution and disease-related mortality, considering its impact on the reduction of opportunistic infections and increase in survival rate and quality of life of 19.5 millions of people with access to treatment on a global level(1-2).

However, evidence that prolonged use of anti-retroviral therapy (HAART) implies challenges for both the client and the health team. One of the major problems faced in care to people living with HIV/aids (PLWHA) is retention in the health service by means of regular tests for the follow-up of the clinical prognosis and attendance to consultations with the health team, to achieve adequate levels of adherence to treatment, promote quality of life and prevent opportunistic infections ${ }^{(3)}$.

In order to incorporate the recommendations proposed by the Ministry of Health in the daily routine of confronting this chronic condition, it is necessary to establish a therapeutic partnership relationship between the client and the health professionals, based on empathy, autonomy and bond, so that the patient feels free to express anxieties, fears and desires related to living with HIV/aids ${ }^{(4)}$.

Accordingly, a need for care tools aimed at follow-up and continuous advice as well as the need for innovative strategies for guiding and training patients with a focus on encouraging the active participation of PLWHA in therapy are evident ${ }^{(1,4)}$. Among these technologies, there are social media, defined as a variety of internet-based tools to help users connect, collaborate and communicate with others in real time ${ }^{(5)}$.

One of the most prominent social media currently is WhatsApp Messenger, an internet-based instant messaging application ${ }^{(6-7)}$. Despite the potential use of this feature to optimize communication and health education in several scenarios, a limited number of studies proposed assessing such use ${ }^{(8)}$.

Acknowledging such a gap, this research focused on answering the following question: can the application WhatsApp be used as a tool to improve care for PLWHA? Studies with this approach may offer subsidies to professionals and researchers to expand communicational tools in order to improve health services accessibility and provide professional support for the reach of care, i.e. the maintenance of regular follow-up of patients at health services beyond the intake of antiretroviral drugs.

\section{OBJECTIVE}

To assess a specific instant messaging application as a tool of care for people living with HIV/aids, based on analysis of the interactions between nurse and patients.

\section{METHOD}

\section{Ethical aspects}

This study was approved by the Research Ethics Committee of the Federal University of Ceará.

\section{Design, study location and period}

Descriptive, quantitative study conducted from July 2016 until January 2017 in two outpatient infectious disease clinics of Fortaleza, Ceará. The two institutions are integrated to the Unified Health System (SUS) and consist of reference centres that offer multidisciplinary care, as well as dispensing of antiretroviral drugs and follow-up tests.

\section{Selection of the sample}

The initial sample was constituted by 102 PLWHA. Participants were recruited at health services through verbal invitation while waiting for the medical appointment. Non-probability sampling (for convenience) and the following inclusion criteria were adopted: being PLWHA aged over 18 years, literate, with own cell phone with internet access, using the application WhatsApp and allowing to receive telephone messages. The exclusion criterion was evidence of physical, mental or visual impediment that limited the reception of messages.

The following were discontinuity criteria: expression of desire to no longer participate in the study; change of telephone number; absence of confirmation regarding the message received after 15 days being sent, and non-attendance at the health service after three months of telephone follow-up completion. By the time the study was complete, there was a follow-up loss of 17 participants, with the final sample consisting of 85 people. The reasons for loss were non attendance at the health service after three months of completing the telephone monitoring ( $n=8)$, no confirmation of the message received after 15 days $(n=4)$, change of telephone number $(n=3)$ and expression of desire to no longer participate in the research $(n=2)$.

\section{Study protocol}

The study was carried out in three phases: recruitment, sending messages and satisfaction assessment regarding the follow-up received. At the moment of recruitment, a form for sociodemographic and clinical characterization for PLWHA previously applied in other research ${ }^{(9)}$ was filled, in order to capture sociodemographic, clinical, epidemiological variables as well as the life habits of participants.

Each participant received an individual standardized message sent biweekly for a period of four months, totaling eight messages for each participant. These messages were validated by experts in a previous study ${ }^{(10)}$ and sent by a nurse through the application WhatsApp, at commercial days and times, addressing one of the following themes: adherence to antiretroviral therapy; physical activity; social support; self-esteem; anxiety/depression; eating habits; alcohol and drugs; sexuality. At the same time, the participants also received images with motivational phrases. The standardization of the messages was used to facilitate the replication of this care tool in specialized assistance services for PLWHA.

Participants were requested to confirm the reception of this standardized message, in the most convenient way possible (text message, audio, or ideograms - specific smileys of WhatsApp called emoji). It should be noted that the moment of the telephone follow-up corresponded to the average return of patients to the service for medical consultation at the time of completion of this study. 
In addition, participants were free to interact spontaneously with the nurse, with the objective of clarifying doubts related (or not) to the topics covered in the standardized messages.

At the end of four months of follow-up, the researchers returned to the health service to apply the adapted version of the Satisfaction Scale for Automated Telephone Disease Management (ATDM), translated and validated for Brazil( ${ }^{(11)}$, originally used to evaluate the telephone follow-up of people with diabetes mellitus. The scale included nine items that assessed: comprehension of information, interest and satisfaction regarding the messages received; the participant's difficulties in responding to messages; safety of the nurse in the transmission of information; learning mediated by messages; use of messages as a reminder to health care; whether the messages were a nuisance; and the frequency of sending messages. For each item, there were five response alternatives, with scores ranging from 1 to 5 points. The ranking of items in the instrument occurs by means of a variation of the Likert scale: (1) always; (2) almost always; (3) sometimes; (4) rarely and (5) never. Participants were also asked about the interest to continue receiving messages, as well as with regard to possible suggestions for improving the follow-up.

\section{Results analysis and statistics}

For analysis of the results, characterization of the participants, of the nurse-patient interactions as well as the satisfaction with messages received was conducted. The data were entered in the application Microsoft Excel 2007 and exported to the statistical software application R, version 3.3.2 for Windows, for performing descriptive statistical analysis using absolute and relative frequencies, in addition to measures of mean central tendency values and standard deviation.

\section{RESULTS}

Most participants were male (96.07\%), single (77.45\%), employed (76.47\%), homosexual/bisexual (89.21\%), with an average age of 30.65 years $( \pm 9.27), 12.85$ average years of education $( \pm 3.42)$, had time of diagnosis less than three years $(71.56 \%)$, cell count CD4+ $\geq 500$ cells $/ \mathrm{mm}^{3}(66.66 \%)$ and viral load $\leq 200$ copies $/ \mathrm{mm}^{3}$ (82.35\%).

There were, in total, 816 interactions after biweekly sending of the individual messages by the nurse. In most cases, participants confirmed reception within the first 24 hours (92.03\%). Regarding the type of feedback provided after delivery of the message, (45.95\%) just read, (25.98\%) were thankful, (18.25\%) confirmed the reception with an emoji, and $7.35 \%$ established a dialogue with the nurse, not necessarily related to the topic discussed in the message. The messages that generated a higher amount of interactions were related to the subjects anxiety/depression (18.69\%), adherence to antiretroviral therapy (17.10\%) and eating habits (14.73\%) (Table 1).

Analysis of the dialogue subjects between the nurse and the participants after reception of the messages indicated a predominance of the subjects physical activity (27.87\%), sharing of signs and symptoms related to acute diseases (18.03\%), report of engagement with the treatment $(9.84 \%)$ and request of information on the intake of medications - delay and loss of doses (9.84\%) (Table 2).
Table 1 - number of interactions related to each of the subjects addressed in the biweekly messages $(n=421)$, Fortaleza, Ceará, Brazil, 2017

\begin{tabular}{lcc}
\hline Interactions according to each subject & $\mathbf{n}$ & $\%$ \\
\hline Adherence to antiretroviral therapy & 72 & 17.10 \\
Physical activity & 51 & 12.11 \\
Social support & 52 & 12.35 \\
Self-esteem & 49 & 11.64 \\
Anxiety/depression & 45 & 10.69 \\
Eating habits & 62 & 14.73 \\
Alcohol and drugs & 49 & 11.64 \\
Sexuality & 41 & 9.74 \\
*Total & 421 & 100 \\
\hline
\end{tabular}

Note: * Communications in which participants only read the messages were excluded.

Table 2 - Characterization of the dialogue subjects between nurse and the participants after reception of the biweekly messages $(n=61)$, Fortaleza, Ceará, Brazil, 2017

\begin{tabular}{lcc}
\hline Subjects of interactions & $\mathbf{n}$ & $\%$ \\
\hline Managing side effects of antiretroviral drugs & 4 & 6.56 \\
Information on intake of antiretroviral drugs & 6 & 9.84 \\
Sexuality and sexually transmitted infections & 4 & 6.56 \\
Referral to a nutritionist & 1 & 1.64 \\
Practice of physical activity & 17 & 27.87 \\
Signs and symptoms of acute diseases & 11 & 18.03 \\
Socialization of positive results of tests & 4 & 6.56 \\
Engagement with the treatment & 6 & 9.84 \\
Difficulties with treatment & 3 & 4.92 \\
Consumption of alcohol and drugs & 4 & 6.56 \\
Social rights & 1 & 1.64 \\
Total & 61 & 100 \\
\hline
\end{tabular}

The interactions generated by spontaneous demand of participants themselves were also stressed. Most of these interactions had as purpose the clarification of doubts on the subjects covered in the messages (42.86\%) regarding specifically: side effects of antiretroviral drugs $(n=4)$; loss or delay of antiretroviral drug dose $(n=10)$; sexuality and sexually transmitted infections $(n=6)$; use of dietary supplements $(n=1)$; reports of signs and symptoms of acute diseases ( $n=2$ ); HIV monitoring tests ( $n=$ $6) ;$ HIV cure $(n=3)$; physical exercise $(n=2)$; and social rights ( $n$ $=2$ ). Request of information on the functioning of the health services investigated was another highlighted interaction type (23.81\%), mainly encompassing the confirmation of the days and schedules in which follow-up examinations were performed, as well as the working hours of the pharmacy.

Regarding acceptability to follow-up, the participants were interested in continuing receiving messages (90.58\%). Based on the answers from the questionnaires using the Satisfaction Scale for Automated Telephone Disease Management $(n=85)$, the majority reported that the words used in the messages have always been easy to understand (92.94\%); they never had difficulty responding to messages (78.82\%); the nurse always shown reliability with regard to the health status of the participant (81.17\%); and always having learned something new about 
self-care (36.47\%). In addition, $50.59 \%$ considered the messages as always interesting; $94.11 \%$ as a reminder to perform carerelated treatment; $90.59 \%$ always liked receiving these messages; $89.41 \%$ never found them a nuisance; $68.23 \%$ always considered the sending frequency adequate.
Regarding anxiety and depression in PLWHA, evidence shows that such problems are directly related to the stigma of the disease, where the prevalence of these disturbances is higher in this target audience compared to the general population ${ }^{(16)}$.

Regarding the use of the phone as a tool for emotional support, a review indicated that this is a viable and acceptable tool for improvement of psychological results in PLWHA, being an effective means to promote individual and group psychotherapy ${ }^{(17)}$.

With regard to the thematic adherence to antiretroviral therapy, similarly to this research, evidence

\section{DISCUSSION}

The sociodemographic profile of the participants converged with the data from Epidemiological Bulletin of 2016, which demonstrates a higher number of cases among men, between the ages of 20 to 34 years old, stated as being homosexual or bisexual ${ }^{(12)}$. This profile was also found in research conducted in Peru, which evaluated advice from men who have sex with men with HIV in early treatment based on messaging via mobile phone or internet ${ }^{(13)}$.

Regarding clinical characteristics, most participants presented diagnosis of recent anti-HIV positive serology as well as good health, observed according to the levels of lymphocytes $T$ CD4+ $\geq 500$ cells $/ \mathrm{mm}^{3}$ and viral load $\leq 200$ copies $/ \mathrm{mm}^{3}$. These results may justify the interest in receiving information for health maintenance and prevention of comorbidities. As evidenced in another study, in people with up to five years of diagnosis, the level of knowledge about this condition was unsatisfactory and demonstrated the need for additional information regarding how to handle the disease ${ }^{(14)}$.

The fast feedback provided by the participants after the messages were sent by the nurse showed good adherence to the use of the application, as well as the availability of internet access. Moreover, this result reinforced one of the great advantages of the use of social media in healthcare actions - the exchange messages in real-time ${ }^{(5)}$. With regard to this aspect, a review found high variation in response rates to messages, ranging from 22 to $100 \%{ }^{(15)}$.

Despite the stimulus towards interactions by means of messages sent by the nurse, a reduced number of participants initiated conversation with the professional. This result can be associated with the educational level of participants, which in turn may be associated with appropriate prior knowledge on the subjects discussed. On the other hand, anxiety/depression issues, adherence to antiretroviral therapy and dietary habits were highlighted as possible generators of interaction, pointing out gaps in the approach of these subjects in health services, and by the fact that they relate directly to fighting against the disease and health behaviors necessary for the treatment of this chronic condition. demonstrates the effectiveness of mobile technology, mostly in the form of sending short message service (SMS) to promote the improvement of antiretroviral treatment based on alert messages and reminders about taking the antiretroviral drugs appropriately ${ }^{(18)}$. In this study, the follow-up of the nurse through WhatsApp promoted the clarification of doubts from participants on the side effects of antiretroviral drugs and intake of medicine, especially with regard to delay

3.57
10.71
23.81
5.95
42.86
13.10
100
and loss of doses, considered important to promote the continuity of treatment and the range/maintenance of viral suppression ${ }^{(15)}$.

On the other hand, healthy eating can improve adherence to and effectiveness of anti-retroviral therapy, contributing to the control of the side effects from antiretroviral drugs, indicating the importance of adequate and safe food guidelines for this population in order to disseminate adequate consumption of food $^{(19)}$. Doubts about dietary changes have also been highlighted in another study conducted in Peru ${ }^{(13)}$.

As for the dialogues generated between nurse and the participants after the messages were received, the practice of physical activity, sharing of signs and symptoms related to acute and clinical manifestations and reports of engagement from the

The promotion of physical activity represents a great potential of the instant messaging service. A study found reduction in sedentary time and increased physical activity through the use of messages via cell phone compared to printed messages ${ }^{(20)}$. On the other hand, the sharing of signs and symptoms related to acute clinical manifestations reveals that the participant understands the nurse as a source of support to talk about their clinical situation and request referrals needed in an emergency situation ${ }^{(13)}$. This provides more quicker response times to follow-up, preventing the aggravation of acute situations.

The account of the participant's engagement with the treatment refers to the need to provide positive feedback for the maintenance of health, as well as motivation strategies. A meta-analysis on interventions for behavioral change indicated that instant messages are capable of producing positive changes in preventive behaviors, and preliminary evidence suggests that these effects can be maintained even when discontinuing intervention ${ }^{(21)}$.

Some participants were shown to spontaneously choose to clarify their doubts. This shows the potential of instant messaging through the application WhatsApp, which allows for the clarification of doubts between appointments in real time, improving the access to the service, reducing costs, and even the time of healthcare. Similar results were found in another study ${ }^{(13)}$, in which participant towards the treatment were observed. 
all participants, in a period of 12 weeks, initiated dialogue with the professional at least once.

Analysis of satisfaction regarding the phone guidance demonstrated interest of the participants to continue receiving messages, having high acceptability $(90.58 \%)$, a similar percentage to that of another study based on a SMS interactive intervention in recently diagnosed PLWHA ${ }^{(22)}$. The messages were also considered easy to understand, reinforcing the results of content validation previously performed by specialists ${ }^{(10)}$. In addition, more than three thirds of the subjects reported never finding it difficult to respond to messages, in addition to never having considered them a nuisance, factors that demonstrate high acceptability of follow-up conducted by a nurse by sending messages through the application WhatsApp.

Most participants reported that the messages worked as a reminder to perform care-related treatment, with encouragement to healthy habits. The frequency of sending messages was considered adequate. This result was also found in a study that used instant messages to change the lifestyle of patients with coronary heart diseases, with $91 \%$ of participants reporting that the messaging program was useful for behavioral changes, with positive rating regarding the sending frequency ${ }^{(23)}$.

\section{Study limitations}

Follow-up losses were considered limitations of this study, as it was not possible to assess the full sample regarding satisfaction with the follow-up. In addition, the use of convenience sampling may limit the generalizability of the study to other populations. Although the standardization of messages facilitates the replication of this proposal in services of specialized assistance, it was considered to be a limitation of the study, considering the possibility of decreasing satisfaction and acceptability of participants.

\section{Contributions to the field of Nursing}

The study allowed to thoroughly analyze the interactions between nurse and PLWHA based on the use of the mobile application WhatsApp, providing subsidies for researchers and professionals to use this tool to enhance communication, bond and care offered in specialized assistance services in HIV/aids at a national level.

\section{FINAL CONSIDERATIONS}

This study demonstrated the favorable possibility of using the mobile application WhatsApp ${ }^{\circledast}$ as a tool of care to PLWHA. Good acceptance and satisfaction was observed regarding the follow-up conducted, with strengthening of the instant communication with the patient. Thus, the inclusion of this technology to enhance the on-site communication commonly offered in health services is something feasible, provided there is an adequate infrastructure in health services and the confidentiality and ethical recommendations related to its use are respected. Further comparative studies that can evaluate the effectiveness of planned and spontaneous interventions among participants is encouraged by the authors, as well as a more comprehensive analysis of the factors related to increased use of this application by PLWHA.

\section{FUNDING}

National Science and Technology Council (CNPq) - funding for research and doctorate scholarship.

\section{REFERENCES}

1. Deekz SG, Lewin SR, Havlir DV. The end of AIDS: HIV infection as a chronic disease. Lancet [Internet]. 2013 [cited 2017 Oct 2];382(9903):152533. Available from: http://www.thelancet.com/pdfs/journals/lancet/PIIS0140-6736(13)61809-7.pdf

2. The Joint United Nations Programme on HIV/AIDS (UNAIDS). Ending AIDS: progress towards the 90-90-90 targets [Internet]. 2017 [cited 2018 Jan 11]. Available from: http://www.unaids.org/sites/default/files/media_asset/Global_AIDS_update_2017_en.pdf

3. The Joint United Nations Programme on HIV/AIDS (UNAIDS). Global Report: UNAIDS report on the Global Aids Epidemic, 2012.2012 [cited 2017 Oct 2]. Available from: http://www.unaids.org/sites/default/files/media_asset/20121120_UNAIDS_Global_Report_2012_with_ annexes_en_1.pdf

4. Zuge SS, Paula CC, Brum CN, Ribeiro AC, Padoin SMM. Adherence to antiretroviral treatment for HIV and inter-its relationship with the programmatic vulnerability. Rev Pesqui: Cuid Fundam [Internet]. 2015 [cited 2017 Oct 2];7(4):3406-17. Available from: http://www.seer. unirio.br/index.php/cuidadofundamental/article/view/4907/pdf_1727

5. Ventola CL. Social media and health care professionals: benefits, risks, and best practices. P\&T [Internet]. 2014 [cited 2017 Oct 2];39(7):491520. Available from: https://www.ncbi.nlm.nih.gov/pmc/articles/PMC4103576/pdf/ptj3907491.pdf

6. Daniel F, Jabak S, Sasso R, Chamoun Y, Tamim H. Patient-physician communication in the era of mobile phones and social media apps: cross-sectional observational study on Lebanese physicians' perceptions and attitudes. JMIR Med Inform [Internet]. 2018 [cited 2018 Apr 10];6(2):e18. Available from: https://www.ncbi.nlm.nih.gov/pubmed/29625955

7. Mesquita AC, Zamarioli CM, Fulquini FL, Carvalho EC, Angerami ELS. Social networks in nursing work processes: an integrative literature review. Rev Esc Enferm USP [Internet]. 2017 [cited 2017 Oct 2];51(3219). Available from: http://www.scielo.br/pdf/reeusp/v51/1980-220Xreeusp-51-e03219.pdf

8. Veneroni L, Ferrari A, Acerra S, Massimino M, Clerici CA. [Considerations on the use of WhatsApp in physician-patient communication and relationship]. Recenti Prog Med. 2015;106(7):331-6. Available from: https://www.ncbi.nlm.nih.gov/pubmed/26228724 Italian

9. Cunha GHD, Galvão MTG. Sociodemographic context of patients with HIV/aids attended in nursing consultation. J Nurs UFPE[Internet]. 
2011 [cited 2017 Oct 2];5(3):713-21. Available from: https://periodicos.ufpe.br/revistas/revistaenfermagem/article/view/6778/6025

10. Lima ICV, Galvão MTG, Pedrosa SC, Silva CAC, Pereira MLD. Validation of phone messages to promote health in people with HIV. Acta Paul Enferm [Internet]. 2017 [cited 2017 Oct 2];30(3):116-21. Available from: http://www.scielo.br/pdf/ape/v30n3/en_1982-0194-ape-30-03-0227.pdf

11. Balaminut T, Landim CAP, Becker TAC, Santos ECB, Olivatto GM, Zanetti ML, et al. Cultural adaptation and reliability for Brazil of the Automated Telephone Disease Management: preliminary results. Acta Paul Enferm [Internet]. 2012 [cited 2017 Oct 2];25(5):795-801. Available from: http://www.scielo.br/pdf/ape/v25n5/en_aop2512.pdf

12. Ministério da Saúde (BR). Secretaria de Vigilância em Saúde. Boletim Epidemiológico HIV/Aids-2016. Brasília, DF; 2017.

13. Bayona E, Menacho L, Segura ER, Mburu G, Roman F, Tristan C, et al. The experiences of newly diagnosed men who have sex with men entering the HIV care cascade in Lima, Peru, 2015-2016: a qualitative analysis of counselor-participant text message exchanges. Cyberpsychol Behav Soc Netw[Internet]. 2017[cited 2017 Oct 2];20(6):389-96. Available from: https://www.ncbi.nlm.nih.gov/ pubmed/28622034

14. Silva RAR, Nelson ARC, Duarte FHS, Prado NCC, Costa RHS, Costa DARS. Evaluation of adherence to antiretroviral therapy for AIDS patients. Rev Pesq: Cuid Fundam [Internet]. 2017 [cited 2017 Oct 2];9(1);15-20. Available from: https://www.ssoar.info/ssoar/bitstream/handle/ document/53583/ssoar-revpesquisa-2017-1-silva_et_al-Evaluation_of_adherence_to_antiretroviral.pdf?sequence=1

15. Kannisto KA, Koivunen MH, Valimaki MA. Use of mobile phone text message reminders in health care services: a narrative literature review. J Med Internet Res [Internet]. 2014 [cited 2017 Oct 2];16(10):e222. Available from: https://www.ncbi.nlm.nih.gov/pmc/articles/ PMC4211035/?report=reader

16. Robertson K, Bayon C, Molina J, Mcnamara P, Resch C, Muñoz-Moreno JA, et al. Screening for neurocognitive impairment, depression, and anxiety in HIV-infected patients in Western Europe and Canada. AIDS Care [Internet]. 2014 [cited 2017 Oct 2];26(12):1555-61. Available from: https://www.ncbi.nlm.nih.gov/pmc/articles/PMC4193282/

17. Kempf MC, Huang CH, Savage R, Safren SA. Technology-delivered mental health interventions for people living with HIV/AIDS (PLWHA): a review of recent advances. Curr HIV/AIDS Rep [Internet]. 2015 [cited 2017 Oct 2];12:472-80. Available from: https://www.ncbi.nlm.nih.gov/ pmc/articles/PMC4853757/

18. Lima ICV, Galvão MTG, Alexandre HO, Lima FET, Araujo TL. Information and communication technologies for adherence to antiretroviral treatment in adults with HIV/AIDS. Int J Med Inform. 2016;92:54-61. doi: http://dx.doi.org/10.1016/j.ijmedinf.2016.04.013

19. Ministério da Saúde (BR). Secretaria de Vigilância em Saúde, Departamento de DST, Aids e Hepatites virais. Protocolo clínico e diretrizes terapêuticas para manejo da infecção pelo HIV em adultos. Brasília, DF; 2015.

20. Joseph RP, Keller C, Adams MA, Ainsworth BE. Print versus a culturally-relevant Facebook and text message delivered intervention to promote physical activity in African American women: a randomized pilot trial. BMC Womens Health [Internet]. 2015 [cited 2017 Oct 2];15(30):1-68. Available from: https://www.ncbi.nlm.nih.gov/pmc/articles/PMC4407714/

21. Armanasco AA, Miller YD, Fjeldsoe BS, Marshall AL. Preventive health behavior change text message interventions: a meta-analysis. Am J Prev Med [Internet]. 2017 [cited 2017 Oct 2];52(3):391-402. Available from: http://www.ajpmonline.org/article/S0749-3797(16)30586-4/pdf

22. Ruan Y, Xiao X, Chen J, Li X, Williams AB, Wang H. Acceptability and efficacy of interactive short message service intervention in improving HIV medication adherence in Chinese antiretroviral treatment-naïve individuals. Patient Prefer Adherence [Internet]. 2017 [cited 2017 Oct 2];11:221-8. Available from: https://www.ncbi.nlm.nih.gov/pmc/articles/PMC5312688/

23. Chow CK, Redfern J, Hillis GS, Thakkar J, Santo K, Hackett ML, et al. A effect of lifestyle-focused text messaging on risk factor modification in patients with coronary heart disease: a randomized clinical trial. JAMA [Internet]. 2015 [cited 2017 Oct 2];314(12):1255-63. Available from: https://jamanetwork.com/journals/jama/fullarticle/2442937?resultClick=1 